\title{
CHEMICAL COMPOSITION, ANTIOXIDANT AND ANTIMICROBIAL ACTIVITIES OF MENTHA GATTEFOSSEI MAIRE ESSENTIAL OIL
}

\author{
ANA CLARA APROTOSOAIE ${ }^{1}$, NINA CIOCÂRLAN ${ }^{2}$, MIHAI BREBU $^{3}$, ADRIANA TRIFAN $^{1 *}$, \\ ADINA CATINCA GRĂDINARU ${ }^{1}$, ANCA MIRON ${ }^{1}$ \\ ${ }^{I}$ Faculty of Pharmacy, "Grigore T. Popa" University of Medicine and Pharmacy, 16 Universităţii Street, 700115, Iaşi, Romania \\ ${ }^{2}$ Botanical Garden, Academy of Sciences of Moldova, Chişinău, Republic of Moldova \\ ${ }^{3}$ Physical Chemistry of Polymers Laboratory, "Petru Poni" Institute of Macromolecular Chemistry, 41 A Grigore Ghica Vodă \\ Alley, 70048, Iași, Romania
}

*corresponding author: adriana.trifan@umfiasi.ro

Manuscript received: February 2018

\begin{abstract}
The aim of this study was to investigate the chemical composition, the in vitro antioxidant and antimicrobial activities of the essential oil obtained from dried aerial parts of Mentha gattefossei Maire (Lamiaceae Family) cultivated in the Republic of Moldova. Mentha gattefossei essential oil (MgEO) was isolated by hydrodistillation and its chemical profile was evaluated by GC-MS and GC-FID analysis. The main compounds of MgEO were pulegone (57.36\%), neomenthone (28.74\%) and Dlimonene $(1.20 \%)$. MgEO exhibited good free radical scavenging activities $\left(\mathrm{EC}_{50}=3.64 \pm 0.07 \mu \mathrm{g} / \mathrm{mL}\right.$ in DPPH assay and $\mathrm{EC}_{50}=254.12 \pm 8.40 \mu \mathrm{g} / \mathrm{mL}$ in $\mathrm{ABTS}^{\circ+}$ assay) and it showed a weak reducing capacity. The essential oil possessed strong antimicrobial activity against Streptococcus pneumoniae (ATCC 49619) and it was moderate active against Staphylococcus aureus (ATCC 25923). This is the first report on the chemical composition and bioactivity of the essential oil from Mentha gattefossei cultivated in the Republic of Moldova.
\end{abstract}

\section{Rezumat}

Acest studiu a avut drept obiectiv investigarea compoziţiei chimice a activităţii antioxidante in vitro, precum şi a acţiunii antimicrobiene, a uleiului volatil obţinut din părţile aeriene uscate de Mentha gattefossei Maire (familia Lamiaceae) (MgEO) cultivată în Republica Moldova. Compoziţia chimică a uleiului volatil obţinut prin hidrodistilare a fost analizată prin GC-MS şi GC-FID. Componenţii principali identificaţi ai MgEO au fost: pulegona (57,36\%), neomentona (28,74\%) şi D-limonen $(1,20 \%)$. MgEO a prezentat o bună activitate de chelare a radicalilor liberi $\left(\mathrm{CE}_{50}=3,64 \pm 0,07 \mu \mathrm{g} / \mathrm{mL}\right.$ în testul DPPH şi $\mathrm{CE}_{50}$ $=254,12 \pm 8,40 \mu \mathrm{g} / \mathrm{mL}$ în testul $\left.\mathrm{ABTS}^{+}{ }^{+}\right)$şi o slabă capacitate reducătoare. Uleiul volatil manifestă o activitate antimicrobiană puternică asupra Streptococcus pneumoniae (ATCC 49619) și este moderat activ asupra Staphylococcus aureus (ATCC 25923). Acesta este primul studiu referitor la compoziţia chimică şi bioactivitatea uleiului volatil obţinut din Mentha gattefossei cultivată în Republica Moldova.

Keywords: Mentha gattefossei, essential oil, chemical composition, bioactivities

\section{Introduction}

The genus Mentha (Lamiaceae Family) includes 18 species and 11 naturally occurring hybrids distributed all over the world, mainly in the temperate regions of Europe and Asia [8]. Mint species are one of the most useful aromatic and medicinal plants with a significant economic value for food, pharmaceutical, flavour industries, cosmetics, perfumery, confectionery and alcoholic beverages. In therapeutics, mint plants are used mainly for their spasmolytic, carminative, cholagogue, expectorant, antiemetic and antidiarrheal properties [15]. Many of these effects as well as mint specific sensory qualities are chiefly bounded to the composition of essential oil. Mentha gattefossei Maire (Menthe de Perse) is endemic to Morocco and it is used for medicinal purposes and as a food source and also for the extraction of essential oil [5]. This species is listed among the rarest plants in the world and it is mentioned in the IUCN (World Conservation Union) Red List of Threatened Plants as Near Threatened being a plant of global conservation interest $[2,3]$. This paper reports for the first time the chemical composition and the antioxidant and antimicrobial activities of the essential oil isolated from Mentha gattefossei species cultivated in Republic of Moldova within ex situ conservation programmes at international level.

\section{Materials and Methods}

\section{Chemicals}

All chemicals were of analytical grade and were purchased from Sigma-Aldrich GmbH (Steinheim, Germany) and Merck (Darmstadt, Germany). 


\section{Plant material}

The aerial parts of Mentha gattefossei were harvested during flowering stage in July 2017 from the experimental field of Botanical Garden, Academy of Sciences of Moldova, Chişinău, Republic of Moldova. Mentha gattefossei plants were obtained from seeds received by the international exchange with the Botanical Garden from Coimbra, Portugal. A voucher specimen was deposited at the Department of Pharmacognosy, "Grigore T. Popa" University of Medicine and Pharmacy, Iaşi, Romania (MG1/Pharmacog/2017).

Essential oil isolation

$100 \mathrm{~g}$ of powdered air-dried aerial parts of plants were hydro-distilled for $3 \mathrm{~h}$ using a modified Clevenger-type apparatus. The obtained essential oil was subsequently dried over anhydrous sodium sulphate and stored in a sealed dark glass at $-4^{\circ} \mathrm{C}$ until analysis. The extraction yield of $\mathrm{MgEO}$ calculated on a dry weight basis was $2.5 \%(\mathrm{v} / \mathrm{w})$.

$G C$ and $G C-M S$ analysis

GC analysis was accomplished using an Agilent 6890N gas chromatograph equipped with a flame ionization detector (FID) and a HP-5MS capillary column (30 $\mathrm{m} \times$ $0.25 \mathrm{~mm}$ internal diameter, $0.25 \mu \mathrm{m}$ film thickness). The injection volume was $0.2 \mu \mathrm{L} \mathrm{MgEO}$ and the split ratio was 50:1. Helium was used as carrier gas at a flow rate of $1.8 \mathrm{~mL} / \mathrm{min}$. The following temperature programme was performed: $4^{\circ} \mathrm{C} / \mathrm{min}$ from $60^{\circ} \mathrm{C}$ to $220^{\circ} \mathrm{C}, 20^{\circ} \mathrm{C} / \mathrm{min}$ from $220^{\circ} \mathrm{C}$ to $320^{\circ} \mathrm{C}$. The $\mathrm{GC}-$ MS analysis was carried out on the same instrument coupled with an Agilent 5975C mass spectrometer selective detector with electron impact ionization. The column and GC-MS conditions were the same as the ones described above except that helium flow rate was $0.5 \mathrm{~mL} / \mathrm{min}$ and the split ratio was 20:1. Mass spectra were acquired in the scan mode (mass range $15-450 \mathrm{~m} / \mathrm{z})[1,16]$.

Identification of components

The components of $\mathrm{MgEO}$ were identified by comparison of their Kovats Index (KI) relative to standard solution of C8 - C23 n-alkanes under the same chromatographic conditions, and by matching their mass spectral data with those National Institute of Standards and Technology (NIST) library [12]. Concentration of individual components was calculated based on GC-FID peak areas without correction factors. In vitro antioxidant assays

DPPH (2,2-diphenyl-1-picryl-hydrazyl radical) radical scavenging assay. The DPPH radical scavenging capability was estimated according to the modified method of Mighri et al. [11, 16]. The methanolic dilutions of $\mathrm{MgEO}$ with concentrations ranging from $5 \mu \mathrm{g} / \mathrm{mL}$ to $80 \mu \mathrm{g} / \mathrm{mL}$ were used. Butylhydroxianisole (BHA) was used as positive control in all antioxidant assays.

ABTS [2,2-azinobis (3-ethylbenzothiazoline-6-sulfonic) acid] radical cation scavenging assay. The assay was carried out as described by $\operatorname{Re}$ et al. with minor changes [16], using methanolic dilutions of $\mathrm{MgEO}$ with concentrations ranging from 5 to $80 \mathrm{mg} / \mathrm{mL}$.

Reducing Power Assay. The method described by Oyaizu was used to determine the reducing power [16]. The methanolic dilutions of $\mathrm{MgEO}$ with concentrations ranging between $0.6336 \mu \mathrm{g} / \mathrm{mL}$ and $10.1384 \mu \mathrm{g} / \mathrm{mL}$ were used.

Antimicrobial activity

Bacterial species. The antimicrobial activity of $\mathrm{MgEO}$ was investigated against the following standard bacterial strains: Pseudomonas aeruginosa (ATCC 27853) (Gram-negative), Escherichia coli (ATCC 25922) (Gram-negative), Staphylococcus aureus ATCC 25923 (Gram-positive) and Streptococcus pneumoniae (ATCC 49619) (Gram-positive).

Disc diffusion method. In vitro antimicrobial activity of $\mathrm{MgEO}$ was determined by using the agar-diffusion assay [4]. The test was performed on sterile Petri plates (90 mm diameter) using Mueller Hinton agar inoculated with microbial suspension at a density adjusted to a $0.5 \mathrm{McF}$ arland standard $\left(10^{6} \mathrm{CFU} / \mathrm{mL}\right)$. The inoculum was spread on the plates using sterile swabs. The wells with $50 \mathrm{~mm}$ diameter have been made in agar and every well was completely filled with $50 \mu \mathrm{L} \mathrm{MgEO}$. Then, the plates were aerobically incubated for $18-24 \mathrm{~h}$, at $35^{\circ} \mathrm{C}$. As positive controls, there were used antibiotic discs of amoxicillin (25 $\mu \mathrm{g} / \mathrm{disc})$ and ciprofloxacin $(5 \mu \mathrm{g} /$ disc $)$ placed on the medium surface. After incubation, the growth inhibition zones were measured and recorded in $\mathrm{mm}$.

\section{Statistical analysis}

All tests were performed in triplicate, and the results are expressed as mean $\pm \mathrm{SD} . \mathrm{EC}_{50}(\mu \mathrm{g} / \mathrm{mL})$, which is the concentration of $\mathrm{MgEO} /$ positive control that reduces $50 \%$ of the free-radical concentration, was calculated through linear interpolation between values above and below 50\% activity. In reducing power assay, $\mathrm{EC}_{50}$ value represents the concentration of $\mathrm{MgEO} /$ positive control that leads to an absorbance of 0.5 .

\section{Results and Discussion}

\section{Chemical composition of essential oil}

The hydrodistillation of dried aerial parts of Mentha gattefossei gave a green oil with strong minty and herbaceous flavour. Twenty-three compounds were identified representing about $90.87 \%$ of total oil composition (Table I). The major components were pulegone $(57.36 \%)$, neomenthone $(28.74 \%)$ and Dlimonene (1.20\%). Oxygenated monoterpenes constitute the dominant fraction of $\mathrm{MgEO}(87.03 \%)$ followed by monoterpene hydrocarbons $(2.73 \%)$. The monoterpeneketones prevail in the composition of oxygenated monoterpenes ( $86.53 \%$ from $87.03 \%$ ). To the best of our knowledge, only one study reported data about the chemical composition of Mentha gattefossei essential 
FARMACIA, 2018, Vol. 66, 5

oil identifying pulegone (56.9\%), menthone (30\%) and piperitenone (3.4\%) as the main compounds [6]. Our results are in agreement with those previously reported. Also, pulegone was detected as major component in the essential oils of Mentha pulegium (76\% - 78\%), M. canadensis (1.5\% - 81.5\%), M. cervina $(31.7 \%-60.8 \%)$, or M. arvensis $(54.6 \%)$ while menthone is one of the main components of M. piperita essential oil $(8.1 \%$ - 31.6\%) $[9,10]$. Among Mentha species, Mentha gattefossei is closely related to M. cervina as suggests the evidence of chloroplast DNA sequences for assessing the phylogenetic relationships in Mentha genus [3].

Table I

Chemical composition of Mentha gattefossei essential oil

\begin{tabular}{|c|l|c|c|}
\hline Peak & \multicolumn{1}{|c|}{ Compound } & $\mathrm{RI}^{\mathrm{a}}$ & $\%$ \\
\hline 1 & $\alpha$-Pinene & 939 & 0.52 \\
\hline 2 & Camphene & 952 & 0.03 \\
\hline 3 & $\beta$-Pinene & 980 & 0.85 \\
\hline 4 & $\beta$-Myrcene & 990 & 0.08 \\
\hline 5 & Octanal & 1002 & 0.05 \\
\hline 6 & Pseudolimonene & 1018 & 0.01 \\
\hline 7 & p-Cymene & 1024 & 0.08 \\
\hline 8 & D-Limonene & 1027 & $\mathbf{1 . 2 0}$ \\
\hline 9 & $\beta$-Phellandrene & 1030 & 0.03 \\
\hline 10 & Eucalyptol & 1033 & 0.33 \\
\hline 11 & $\gamma$-Terpinene & 1062 & 0.01 \\
\hline 12 & $\alpha$-Campholenal & 1127 & 0.02 \\
\hline 13 & Hexenyl isobutanoate & 1142 & 0.41 \\
\hline 14 & Pinocarveol & 1146 & 0.11 \\
\hline 15 & Neomenthone & 1158 & $\mathbf{2 8 . 7 4}$ \\
\hline 16 & Myrtenol & 1184 & 0.04 \\
\hline 17 & Pulegone & 1236 & $\mathbf{5 7 . 3 6}$ \\
\hline 18 & Piperitone & 1251 & 0.43 \\
\hline 19 & o-Cymen-5-ol & 1334 & 0.03 \\
\hline 20 & Phenylbutyrate & 1245 & 0.05 \\
\hline 21 & Mint furanone & 1291 & 0.01 \\
\hline 22 & Hydroxyacetophenone & 1447 & 0.06 \\
\hline 23 & Caryophyllene oxide & 1578 & 0.42 \\
\hline Group of constituents (\%) & \multicolumn{3}{|c|}{2.73} \\
\hline Monoterpene hydrocarbons & 87.03 \\
Oxygenated monoterpenes & 0.42 \\
Sesquiterpenes & 0.22 \\
Aromatic compounds & 0.47 \\
\hline Non-terpenoid aliphates & $\mathbf{9 0 . 8 7}$ \\
\hline Total identified (\%) & \\
\hline
\end{tabular}

${ }^{a}$ Retention indices relative to $\mathrm{C} 8$ - $\mathrm{C} 20$ n-alkanes calculated on HP-5MS capillary column

\section{In vitro antioxidant activity}

$\mathrm{MgEO}$ was screened for its antioxidant activities in vitro using free radicals (DPPH and $\mathrm{ABTS} \bullet^{+}$) scavenging assays and also the reducing power assay. DPPH scavenging activity of MgEO increased dosedependently from $36.88 \pm 0.81 \%$ at $2.5 \mu \mathrm{g} / \mathrm{mL}$ to $81.51 \pm 0.63 \%$ at $40 \mu \mathrm{g} / \mathrm{mL}$ (Figure $1 \mathrm{~A}$ ). Also, ABTS ${ }^{+}$scavenging activity of $\mathrm{MgEO}$ ranged from $13.40 \pm 0.33 \%$ at $50 \mu \mathrm{g} / \mathrm{mL}$ to $84.56 \pm 0.11 \%$ at
$800 \mu \mathrm{g} / \mathrm{mL}$ after $6 \mathrm{~min}$ reaction time (Figure 1B). The positive control, BHA almost completely scavenged the DPPH radical $(94.96 \pm 0.35 \%)$ at $10 \mu \mathrm{g} / \mathrm{mL}$ and it exhibited $100 \% \mathrm{ABTS}^{+}{ }^{+}$scavenging effects at $200 \mu \mathrm{g} /$ $\mathrm{mL}$ (Figure 1). MgEO was more effective as DPPH free radical scavenger than as ABTS ${ }^{+}$inhibitor (Table II). Also, MgEO was similarly effective as BHA in terms of DPPH scavenging activity $\left(\mathrm{EC}_{50}=3.64 \pm 0.07\right.$ vs. $\mathrm{EC}_{50}=3.30 \pm 0.15$ ) (Table II). Regarding the reducing power assay, $\mathrm{MgEO}$ showed a weak reducing capacity. Thus, $\mathrm{EC}_{50}$ in this assay could not be calculated because $\mathrm{MgEO}$ showed an absorbance value of 0.2 at a concentration of $0.4848 \mu \mathrm{g} / \mathrm{mL}$, and the increase of the tested concentration was not possible due to low solubility of the oil in the reaction medium. The antioxidant activity of mint essential oils was largely investigated but this is the first study on the antioxidant properties of Mentha gattefossei essential oil. Although a direct comparison cannot be achieved, we must say, however, that the MgEO showed more efficient free radical scavenging properties than other Mentha essential oils with high concentrations of monoterpene ketones such as pulegone and menthone. Thus, Kamkar et al. (2010) reported for the essential oil from Iranian Mentha pulegium (with $40.5 \%$ pulegone and $35.4 \%$ menthone) an $\mathrm{EC}_{50}$ value of $14736 \mu \mathrm{g} / \mathrm{mL}$ in DPPH assay. In our study, $\mathrm{EC}_{50}$ of MgEO in DPPH assay was $3.64 \mu \mathrm{g} / \mathrm{mL}$ (Table II) [7].

A



B

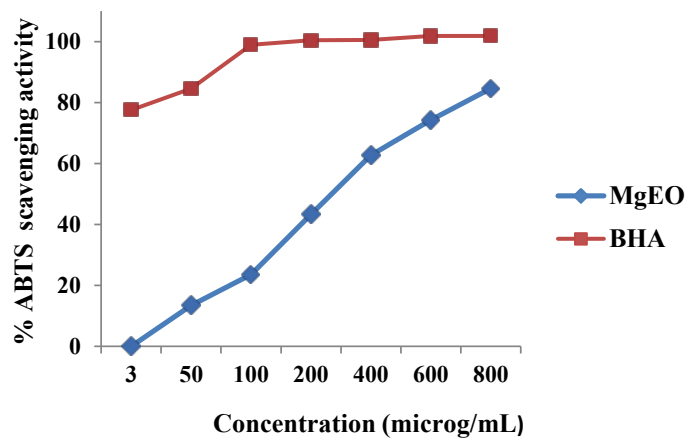

Figure 1.

Free radial scavenging activity of Mentha gattefossei essential oil (MgEO): A) DPPH radical scavenging activity; B) ABTS radical cation scavenging activity;

BHA, butylhydroxyanisole as positive control 
Antioxidant activity of Mentha gattefossei essential oil

\begin{tabular}{|c|c|c|c|}
\hline \multirow{2}{*}{ Essential oil/positive control } & \multicolumn{3}{|c|}{$\mathrm{EC}_{50}(\mu \mathrm{g} / \mathrm{mL})$} \\
\cline { 2 - 4 } & DPPH assay & ABTS $^{+}$assay & Reducing power assay \\
\hline MgEO & $3.64 \pm 0.07$ & $254.12 \pm 8.40$ & - \\
\hline BHA & $3.30 \pm 0.15$ & $1.9 \pm 0.10$ & $4.26 \pm 0.10$ \\
\hline
\end{tabular}

\section{In vitro antimicrobial activity}

The agar-diffusion assay showed a strong antibacterial activity (inhibition zone $\geq 20 \mathrm{~mm}$ ) of MgEO against Streptococcus pneumoniae (ATCC 49619) bacteria but lower than antibiotics used as positive controls (Table III). Also, MgEO showed moderate activity on Staphylococcus aureus (ATCC 25923). The standard strains Gram-negative bacteria of Pseudomonas aeruginosa and Escherichia coli were non-sensitive to MgEO (Table III). Although pulegone, the major component of $\mathrm{MgEO}$, has a potent biocide activity on both Gram-positive and Gram-negative bacteria, however the essential oil behaves differently. The antimicrobial efficacy of the MgEO itself is determined by its entire chemical composition. In this respect, other important components of MgEO such as neomenthone and limonene have proven to be less effective against the tested microorganisms [14]. The higher antimicrobial effects of MgEO against Gram-positive than Gramnegative bacteria, could be explained by the structure of cell envelope. Thus, the structure and the composition of cell wall and outer membrane of Gram-negative bacteria are more complex and contribute significantly to the occurrence of certain resistance to the passage of antimicrobial agents such as essential oils [13].

The antibacterial activity of $M$. gattefossei essential oil (MgEO) and conventional antibiotics against the tested

Table III

bacteria

\begin{tabular}{|c|l|c|c|c|}
\hline \multicolumn{2}{|c|}{ Bacterial strains } & \multicolumn{2}{c|}{ Diameter of inhibition zone (mm) } \\
\cline { 3 - 5 } \multicolumn{2}{|c|}{} & MgEO & \multicolumn{2}{c|}{ Standard drugs } \\
\cline { 3 - 5 } & & & Amoxicillin & Ciprofloxacin \\
\hline G- & Pseudomonas aeruginosa (ATCC 27853) & $0.00 \pm 0.00$ & $0.00 \pm 0.00$ & $26.33 \pm 0.57$ \\
\hline G- & Escherichia coli (ATCC 25922) & $0.00 \pm 0.00$ & $25.00 \pm 0.57$ & $40.00 \pm 0.57$ \\
\hline G+ & Staphylococcus aureus (ATCC 25923) & $10.00 \pm 0.00$ & $25.00 \pm 0.00$ & $30.00 \pm 0.57$ \\
\hline G+ & Streptococcus pneumoniae (ATCC 49619) & $20.66 \pm 1.15$ & $40.00 \pm 0.00$ & $30.00 \pm 0.00$ \\
\hline
\end{tabular}

\section{Conclusions}

The results from the present study indicated that the essential oil of Mentha gattefossei plants cultivated in the Republic of Moldova is a rich source of monoterpene-ketones as pulegone and neomenthone. Further, it showed good free radical scavenging properties and promising antimicrobial activity on Streptococcus pneumoniae.

\section{References}

1. Aprotosoaie AC, Şpac A, Hăncianu M, Miron A, Tănăsescu VF, Dorneanu V, Stănescu U, The chemical profile of essential oils obtained from fennel fruits (Foeniculum vulgare Mill.). Farmacia, 2010; 58(1): 46-53.

2. Bunsawat J, Elliott NE, Hertweck KL, Sproles E, Lawrence AA, Phylogenetics of Mentha (Lamiaceae): evidence from chloroplast DNA sequences. Syst Bot., 2004; 29(4): 959-964.

3. Ciocârlan N, Mentha gattefossei Maire-a threatened medicinal species cultivated in the Botanical Garden (I) of ASM. Mediul Ambiant, 2014; 2(74): 19-22.

4. Clinical and Laboratory Standards Institute. Performance standards for antimicrobial disk susceptibility tests $\left(10^{\text {th }}\right.$ ed.). Approved standard, CLSI publication M02-A10. Clinical and Laboratory Standards Institute, Wayne Pennsylvania, 2009.
5. Fennane M, Tattou Ibn M, Flore vasculaire du Maroc. Inventaire et chorologie. Trav Inst Sci Univ Mohamed V Ser Bot., 2005; 37: 259.

6. Fujita SI, Moriyoshi K, Essential oil of Mentha gattefossei Maire. Nippon Kagakkai Koen Yokoshu, 2001; 79(2), 1366.

7. Kamkar A, Javan AJ, Asadi F, Kamalinejad M, The antioxidative effect of Iranian Mentha pulegium extracts and essential oil in sunflower oil. Food Chem Toxicol., 2010; 48(7): 1796-1800.

8. Kapp K, Polyphenolic and essential oil composition of Mentha and their antimicrobial effect. Academic Dissertation, Faculty of Pharmacy, University of Helsinki, 2015.

9. Lawrence BM, The composition of commercially important mints. In Lawrence B.M. (ed.) Mint: the genus Mentha. CRC Press, Taylor \&Francis Group, Boca Raton, 2007; 217-325.

10. Lawrence BM, Oil composition of other Mentha species and hybrids. In Lawrence B.M. (ed.) Mint: the genus Mentha. CRC Press, Taylor \&Francis Group, Boca Raton, 2007; 325-347.

11. Lungu Apetrei C, Şpac A, Brebu M, Tuchiluş C, Miron A, Composition, and antioxidant and antimicrobial activities of the essential oils of a full-grown Pinus cembra L. tree from the Calimani Mountains (Romania). J. Serb. Chem. Soc., 2013; 78: 27-37.

12. National Institute of Standards and Technology (NIST). Chemistry WebBook, SRD 69. www.webbook.nist. gov/ cgi/cbook.cgi?ID=127-91-3. 
FARMACIA, 2018, Vol. 66, 5

13. Nazzaro F, Fratianni F, De Martino L, Coppola R, de Feo V, Effect of essential oils on pathogenic bacteria. Pharmaceuticals, 2013; 6(12): 1451-1474.

14. Oumzil H, Ghoulami S, Rhajaoui M, Ilidrissi A, FkihTetouani S, Faid M, Benjouad A, Antibacterial and antifungal activity of essential oils of Mentha suaveolens. Phytother Res., 2002; 16(8): 727-731.

15. Stănescu U, Hăncianu M, Miron A, Aprotosoaie C, Medicinal plants from A to $\mathrm{Z}$; monographs of the therapeutic products (vol. II), Edit. Gr. T. Popa, Iaşi, 2004; 388-393. (available in Romanian)

16. Trifan A, Aprotosoaie AC, Brebu M, Cioancă O, Gille E, Hăncianu M, Miron A, Chemical composition and antioxidant activity of essential oil from Romanian Satureja montana L. Farmacia, 2015; 63(3): 413-416. 